\title{
Fabrication of dye natural as a photosensitizers in dye- sensitized solar cells (DSSC)
}

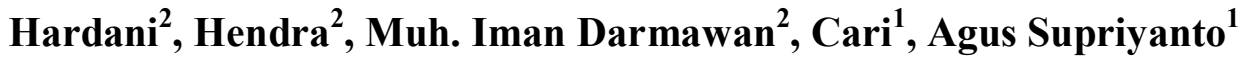 \\ ${ }^{1,2}$ Postgraduate Physics of Sebelas Maret University \\ Jalan Ir. Sutami 36 A, Surakarta 57126 \\ Email: danylastchild07@gmail.com
}

Received 12 October 2016, Revised 24 November 2016, Accepted 19 December 2016

\begin{abstract}
The purpose of this study was to obtain optical properties (absorption spectrum) and electrical properties (photoconductivity) of organic dyes in DSSC performance. optical and electrical properties were tested by using UV-Visible Spectrophotometer and Elkahfi 1601 PC 100 / IV meter, respectively, while Keithley Type $2600 \mathrm{~A}$ is used for the characterization of DSSC. This study is a great base to explore and investigate the development of DSSC solar cells using natural dyes (organic). Spectra optimal absorption and photoconductivity produced by natural dyes (organic). The results of this study indicate that the absorption spectrum of natural dyes (organic) in the range of 300-500 $\mathrm{nm}$. electrical characteristics (I-V) of the increase in linear dye under illumination. I-V characteristics of DSSC from organically produced natural dyes to color the biggest-mangosteen obtained Voc of $565 \mathrm{mV} ; \mathrm{JSC}=1.52 \mathrm{~A} / \mathrm{m} 2 ; \mathrm{FF}=0.12$; and $\eta_{-}$ef is approximately $0.09 \%$, respectively,. The conclusion of this study, natural dyes (organic) can be an attractive alternative as a dye.
\end{abstract}

Keywords: Dye-Sensitized Solar Cell (DSSC); Dye Organic; Dye Sensitizer.

\section{Introduction}

The energy is usually derived from fossil presence increasingly diminished and can not be renewed. Therefore, many experts are looking for ways to create a new energy / alternative, and Dye-sensitized solar cell (DSSC) is one of the new and renewable energy. In this study aims to determine the characterization of the electrical properties of extracts from natural organic materials and organic polymers. Knowing the effects of extracts from natural organic materials and organic polymers to increase the efficiency of solar cells based Dye-sensitized Solar Cells (DSSC).

Currently very own photovoltaic technology advancements in the field of solar energy as an alternative and renewable energy. To produce solar cells at low cost, have many models with structures and new materials currently being developed (Hadipour et al., 2008).

The solar panels are often called photovoltaic cells, photovoltaic can be interpreted as a "light-electricity". 
Organic photovoltaic is an alternative to replace inorganic photovoltaic solar cells and silicon. Polymer conjunction is interesting in this regard.

Solar cells rely on the photovoltaic effect to absorb solar energy and cause current to flow between two opposite charged layer. Total use of solar panels in the world's electricity production portion is very small because it is constrained by the high cost per watt compared to fossil fuel can be ten times higher, depending on the circumstances.

Right now the cost of solar electric panels makes it impractical for everyday use where electricity "cable" has been provided. Organic Photovoltaics has many attractive features including, potentially to the devices that are flexible, can be produced with simple techniques and inexpensive in terms of cost of manufacture (Brabec.C.J. 2004).

Dye-sensitized solar cell (DSSC) is a photoelectrochemical solar cell, mainly consisting of photoelectrode, electrolyte, and a counter electrode. Titanium dioxide $\left(\mathrm{TiO}_{2}\right)$ has become the preferred semiconductors in a variety of studies, unfortunately, due to the band gap is large ( 3 to $3.2 \mathrm{eV}$ ), $\mathrm{TiO}_{2}$ absorbs only an ultraviolet portion of the sun so it has a low conversion efficiency (Grätzel, M. 2001).

The last two decades have found M.Gratzel Dye-sensitized Solar Cell (DSSC) as a photovoltaic devais. Dye-sensitized Solar Cells has attracted attention as a converter of energy compared to silicon solar cells (Cari, et.al, 2013). DSSC uses three active material, an organic dye as a material which absorbs photons, a layer of metal oxide nanocrystal as an electron transport material and liquid or metal oxide layer as a hole transport material (HTM) (Gren Martin, A. 1982).

DSSC is very attractive for further investigation because they allow producing high efficiency with cheap production costs (Cari, et.al, 2013). Several studies using material from platinum $(\mathrm{Pt})$ as the counter electrode in DSSC. Platinum (Pt) and carbon $(\mathrm{C})$ is a material commonly used as the counter electrode. In this study, using a platinum $(\mathrm{Pt})$ as the counter electrode in order to reduce drag on the FTO glass.

In DSSC, natural coloring (dye) as a sensitizer play an important role to absorb photons from sunlight and convert it into electric current. The types of dyes such as metal complexes, natural and organic materials typically used as a sensitizer.

The working principle of DSSC is conversion light energy into electrical energy. When a dye is attached to the surface of $\mathrm{TiO} 2$ absorbs photons of sunlight, electrons are excited into the conduction band of TiO2. Electrons will be collected in TiO2, dye molecule that is left in a state of oxidized. Furthermore, the electron will transfer through the external circuit to the counter electrode.

Performance solar cells are the ability of solar cells conversion light into electrical energy. Figure 1. An I-V curve which shows Traffic cells in producing voltage and current. In the image shown in the open circuit voltage (Voc), short circuit current (Iis), maximum voltage, maximum current and fill factor. When short circuit condition (Iis), the cell will produce a short circuit current. When open circuit condition no current flows so that the voltage will be the maximum, or so-called open circuit voltage. Fill factor is a measure of the quality of the performance of solar cells. 


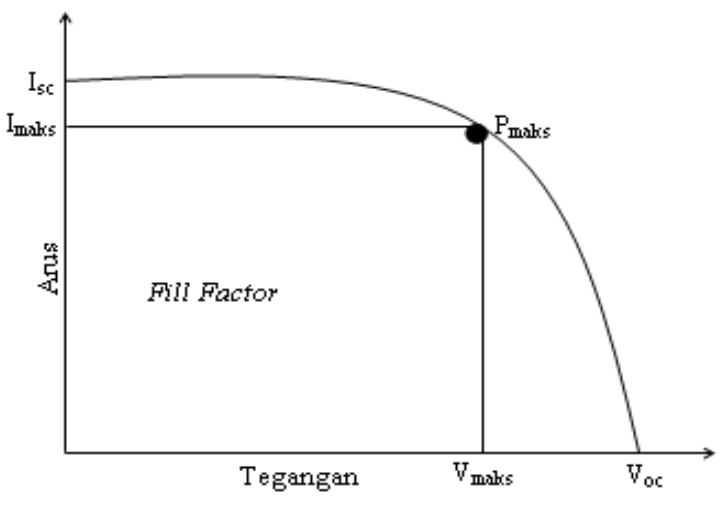

Figure 1. Curve I-V DSSC

Fill Factor (FF) is a quantitative measure of the quality of a solar cell, as well as the size of the square outside the I-V curve, fill factor can be obtained using the equation 1.

$$
F F=\frac{V_{\text {maks }} I_{\text {maks }}}{V_{o c} I_{s c}}
$$

(1)

The maximum power produced by the solar cells can be obtained from the equation 2 .

$$
\begin{gathered}
P_{\text {maks }}=V_{o c} I_{s c} F F \\
(2) \\
\eta=\frac{P_{M A X}}{P_{\text {cahaya }}}
\end{gathered}
$$

The efficiency of solar cells is a quantitative comparison of the maximum power generated cells $\left(\mathrm{P}_{\max }\right)$ with the power of the incoming light $\left(\mathrm{P}_{\text {light }}\right)$ can be determined by the equation 3 .

\section{Research Methods}

$\mathrm{TiO}_{2}$ used in this study is Titanium dioxide (nanopowder) with a size of $21 \mathrm{~nm}$. $\mathrm{TiO}_{2}$ as much as 0.5 grams dissolved in $2 \mathrm{ml}$ of ethanol is stirred for 30 minutes using a vortex stirrer.

$\mathrm{TiO}_{2}$ is coated onto a conductive glass Fluorine Tin Oxide (FTO) by the deposition area of $1.5 \mathrm{~cm} \times 2 \mathrm{~cm}$ using methods Coathing spin. $\mathrm{TiO}_{2}$ layer that has been deposited is heated to a temperature of $5000 \mathrm{C}$ for 60 minutes on a hot plate. This study used a dye of the extract organic material pulverized using a mortar until smooth. Organic material is finely dissolved in $35 \mathrm{ml}$ of ethanol while stirring for 60 minutes and allowed to stand for one day in order to extract dye organic material produced homogeneous. Construction DSSC used is a sandwich system. Working electrode FTO conductive glass coated $\mathrm{TiO}_{2}$ that has been soaked with dye organic material.

The counter electrode in the form of the FTO conductive glass that has been coated a thin layer of Pt (Hexachloroplatinic (IV) acid 10\%). Electrolytes are made from sodium $3.3 \mathrm{~g}$, Iodine $0528 \mathrm{gr}$, HPA $0.005481 \mathrm{gr}$, Acetonitrile $30 \mathrm{ml}$ which spilled between the 
counter electrode and the working electrode is given a barrier to use a keyboard protector to prevent short circuiting.

The working electrode and the counter electrode and the electrolyte that has been poured between them in the pile are then clamped using the clipboard. DSSC then characterized using current and voltage Keithley. As shown in Figure 2.

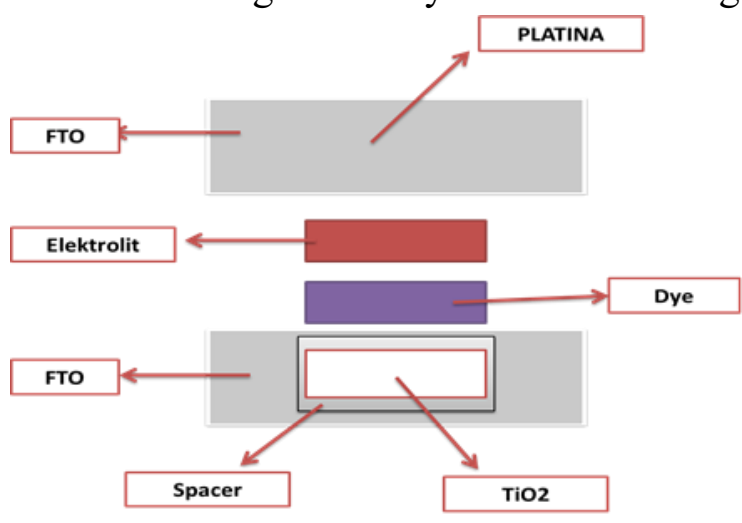

Figure 2. Structure DSSC

\section{Results and Discussion}

The dye solution is made from extracts of organic material that can absorb and pass on the visible light spectrum. The dye serves as Dye-sensitized Solar Cells using extraction of organic materials as a dye sensitizer has been carried out, testing the extraction of organic materials using UV-Visible spectrophotometer 1601 PC to know the power of the absorbance of the extraction of organic material to the visible wavelengths.

Absorbance is measured in the range of 200-800 $\mathrm{nm}$. Results characterization absorbance spectrum in Figure 3 shows that the absorption spectrum extracts organic material contained in the range of 300-800 $\mathrm{nm}$. 

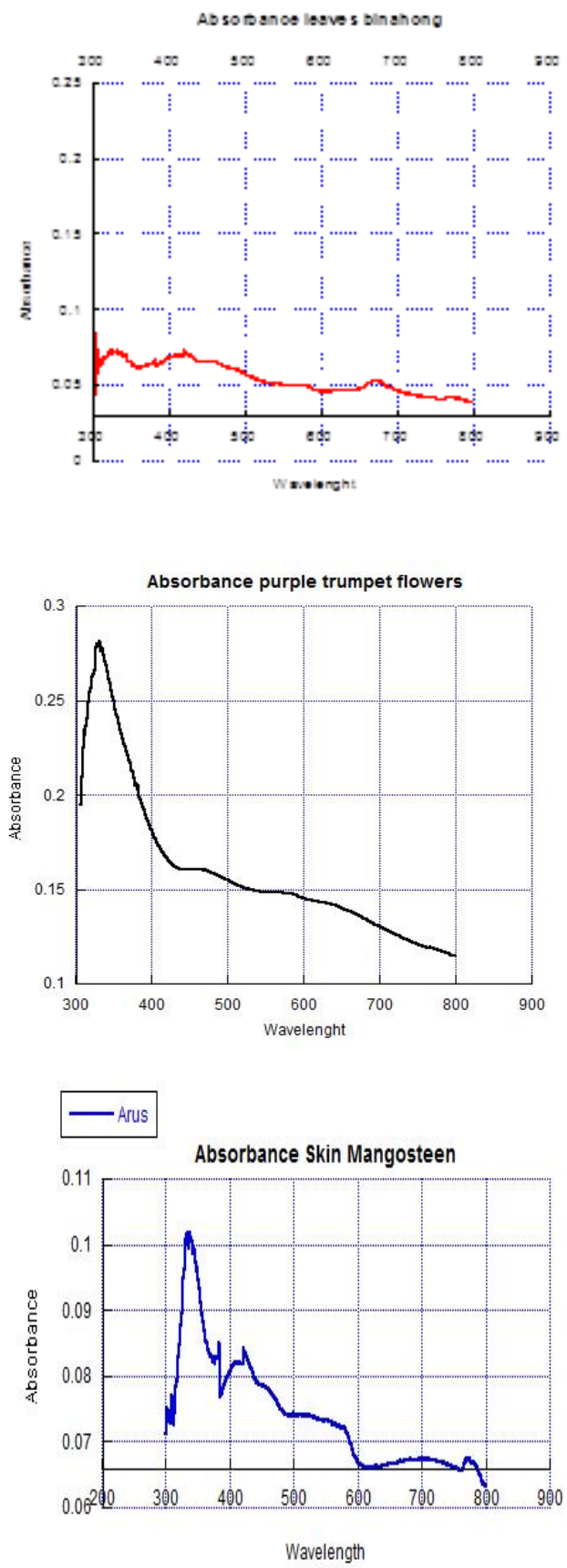

Figure 3. Graph Absorbance extract organic material

Characterization current-voltage (I-V) is a method to determine the performance of Dye-sensitized Solar Cells is how much ability DSSC can convert light into electrical energy measurement of I-V performed under dark and light conditions is under irradiation of halogen lamp with the intensity of $1000 \mathrm{~W} / \mathrm{m}^{2}$. To value the characteristics of DSSC can be seen in Figure 4. 


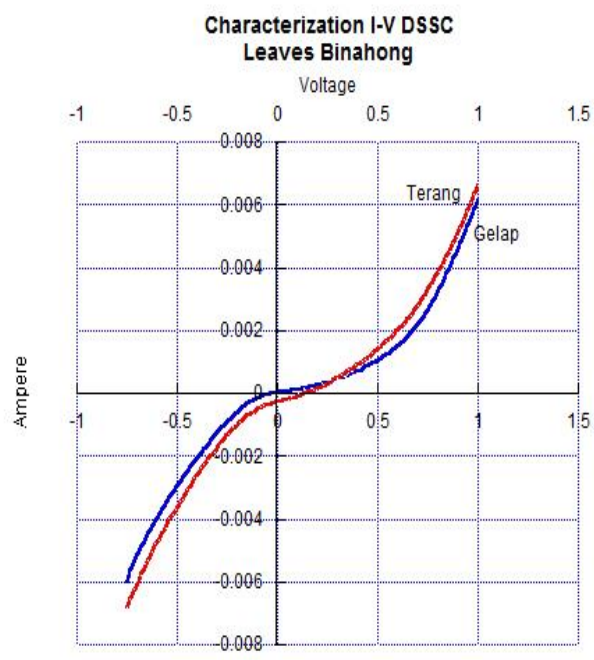

Volt
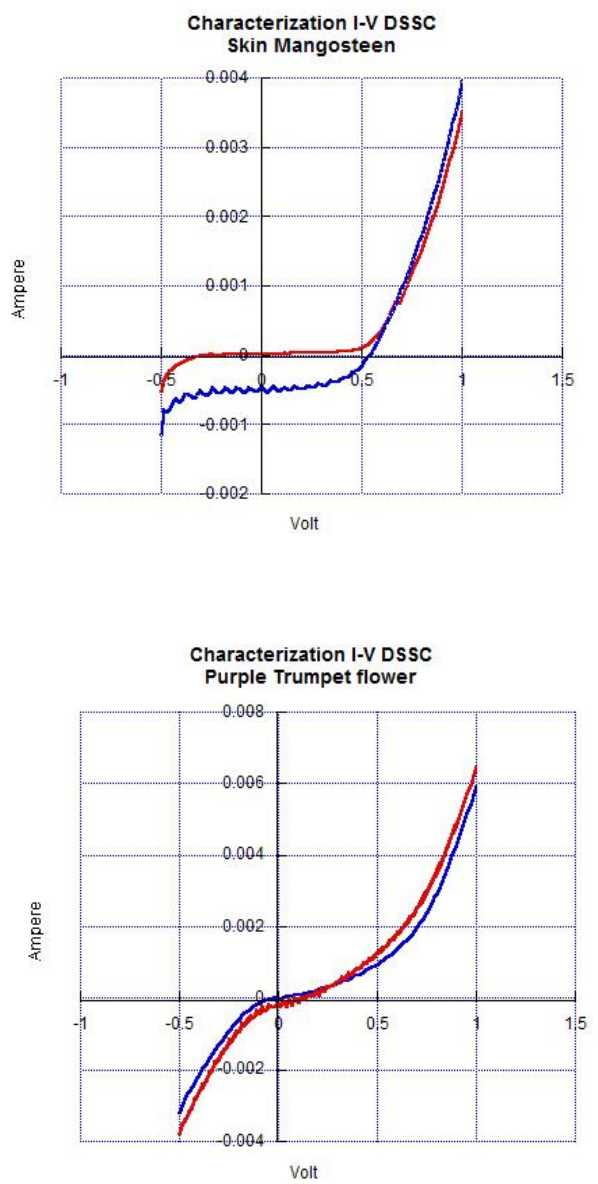

Figure 4. Curve I-V organic materials

From Figure 4 shows the I-V curve values characterization of organic matter in the light of current is greater than the dark current. DSSC efficiencies generated by the use of extracts of organic materials with a treatment difference in $\mathrm{TiO}_{2}$ are presented in Table 1. In this study using Pt counter electrode (Hexachloroplatinic (IV) acid 10\%). 
Table I. DSSC Efficiency

\begin{tabular}{llllll}
\hline Dye & Voc $(\mathrm{mV})$ & Isc $(\boldsymbol{\mu} \boldsymbol{A})$ & FF & Pmax & $\eta(\%)$ \\
\hline Skin Mangosteen & $0.5 \times 10^{-3}$ & $0.3 \times 10^{-6}$ & $1.26 \times 10^{-7}$ & $0.2 \times 10^{-3}$ & $0.9 \times 10^{-1}$ \\
Leaves Binahong & $0.17 \times 10^{-3}$ & $0.38 \times 10^{-9}$ & $5.09 \times 10^{-8}$ & $2.3 \times 10^{-5}$ & $1 \times 10^{-2}$ \\
Purple Trumpet & $0.14 \times 10^{-3}$ & $0.27 \times 10^{-9}$ & $0.8 \times 10^{-2}$ & $1.52 \times 10^{-5}$ & $0.7 \times 10^{-2}$ \\
Flower & & & & & \\
\hline
\end{tabular}

This study used a liquid electrolyte, where the electrolyte is the longer used increasingly depleted due to evaporating and produce less than the maximum transfer catalyst. In accordance with the function of the electrode/charge. If electrolyte depleted or nonexistent, the electron transfer activity will be reduced/no.

\section{Conclusion}

Dye-sensitized Solar Cells (DSSC) using organic materials extraction material with a time difference of immersion has been manufactured. With the current and voltage generated. The area of the curve shows a DSSC from extracts of organic materials by soaking method produces I-V curves well. The counter electrode is one important component of unusual released at DSSC structure.

Giving Pt (Hexachloroplatinic (IV) acid 10\%) on the counter electrode provides better performance in DSSC. Pt (Hexachloroplatinic (IV) acid 10\%) to function as a catalyst in accelerating the redox reaction with the electrolyte. The efficiencies generated by each of the organic material showed good improvement.

\section{Thank-you Note}

Researchers would like to thank the manager of the Laboratory of Natural Sciences UNS Surakarta and support LPPM Graduate Grant No. UNS Surakarta 301A / UN27 / $\mathrm{PN} / 2014$.

\section{References}

Brabec C J. (2004). Organic Photovoltaic: Technology and Market. Journal of Solar Energy Materials \& Solar Cells 83 (2-3) 273-292

Cari, Nurussaniah, Boisandi, Anita, Supriyanto Agus, Suryana Risa. (2013) Studi Pengaruh Konsentarasi Poly (3-Hexylthiophene) (P3HT) Terhadap Peningkatan Efisisensi Dye-Sensitized Solar Cells. Seminar Nasional $2^{\text {nd }}$ Lontar Physics Forum. ISBN: 978-602-8047-80-7:LPF1331-1.

Grätzel, M. (2001). Photoelectrochemical cells. Nature, 414(6861), 338-344..

Green, M.A. (1982). Solar cells: operating principles, technology, and system applications. United States: Prentice-Hall, Inc.,Englewood Cliffs, NJ.

Hadipour, A., de Boer, B., \& Blom, P. W. (2008). Organic tandem and multi-junction solar cells. Advanced functional materials, 18(2), 169-181. 
Hagfeldt, A., \& Grätzel, M. (2000). Molecular photovoltaics. Accounts of Chemical Research, 33(5), 269-277.

Supriyanto, A., \& Suryana, R. (2013). STUDI PENGARUH PENGGUNAAN POLY (3-HEXYLTHIOPHENE) P3HT DAN GRAFIT TERHADAP KINERJA SEL SURYA. Jurnal Fisika, 3(1). 